\title{
Research on the Credit Risk and System Risk of Commercial Banks in China after the European Debt Crisis
}

\author{
Hao-ran Sang ${ }^{1}$ \\ ${ }^{1}$ International Business School, Shaanxi Normal University \\ Xi'an, China \\ Shr0213@163.com
}

\begin{abstract}
In 2009, a sovereign debt crisis affecting the world broke out in Europe. With the development and deepening of the crisis, the European bank's credit risk and systemic risk were gradually exposed. This article attempts to measure the systemic risk by measuring the beta coefficient of commercial banks in China through William Sharp's single index model, and assess the credit risk by KMV model. After observing the changes in risk research of Chinese listed commercial banks after 2009, we find the credit of China's commercial banks. High risk, systemic risk fluctuates and systemic risk in the past three years is on the rise.
\end{abstract}

\section{Keywords-Credit risk; System risk; KMV model}

\section{INTRODUCTION}

The European debt crisis is the extension and deepening of the US subprime mortgage crisis. Its essence is the risk that the government's debt will exceed its own affordability and thus the country may default. The commercial banks and the economic lifeblood of the national economy are closely related to each other, and the crisis behind it must be followed by the crisis of commercial banks. The downgrade of credit ratings and the widespread recognition of systemic risks have exposed the risks of commercial banks to the general public. Nowadays, in the academic community, there is no uniform standard for the assessment of credit risk and the risks of the banking system. Systemic risks are not clearly defined. Based on the European debt crisis, this paper studies the expected default rates of the five major commercial banks in China in 2014 and compares them with Moody's ratings to test whether the model is suitable for the credit risk of China's commercial banks. The systemic risk of China's commercial banks was rated by calculating the beta of five commercial banks in the seven years after the European debt crisis [1]. Comprehensively evaluate the risk status of China's commercial banks and propose corresponding suggestions.

\section{THE CREDIT RISK AND SYSTEM RISK OF CHINA'S COMMERCIAL BANKS}

In the late start of China's commercial banks, there are generally the following issues :

The proportion of bad credit assets is high. The following figure shows the non-performing loan laws of commercial banks in recent years in China.

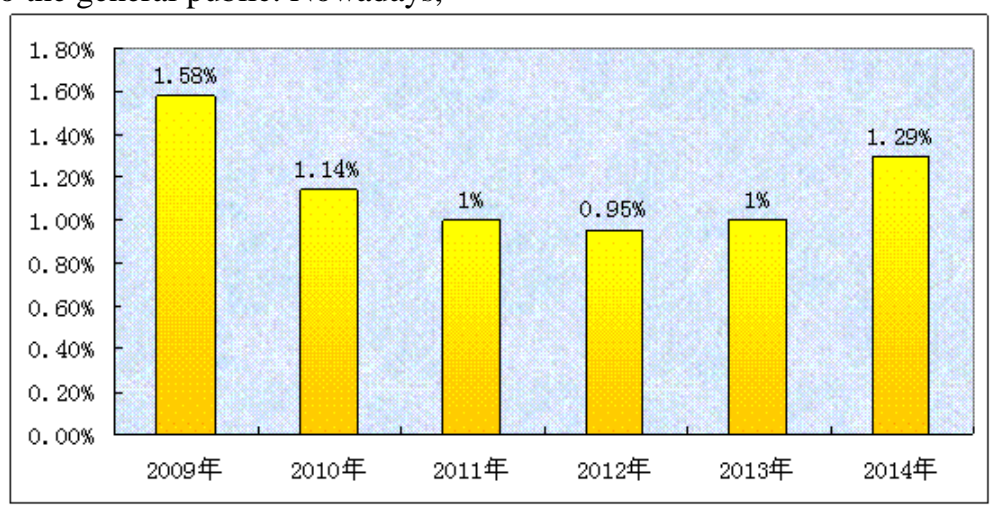

Fig. 1 Non-performing loan rate of commercial banks in China(2009-2014) 
The non-performing loan ratio of China's commercial banks experienced a growth trend after 2012 after a two-year decline after the country's control after the financial crisis. The total value of commercial bank loans is increasing year by year. The bad loan situation is not optimistic.

1.The credit risk is too concentrated and state-owned commercial banks account for the vast majority of risks. At the end of 2010, non-performing loans of state-owned 2.commercial banks accounted for more than $70 \%$ of loans from commercial banks. The current situation of overly concentrated risks is worrying.

3.Lack of an effective credit monitoring system. Lack of information management system reduces the transparency of credit risk

\section{Lack of professional credit risk management talents}

\section{EMPIRICAL ANALYSIS}

KMV Model: The two unknown variables $\mathrm{V}$ and $\sigma \mathrm{V}$ required in the KMV model can be solved from the following equations by the simultaneous equations [2]:

$$
\begin{gathered}
\left\{\begin{array}{lr}
E=V N\left(d_{1}\right)-D e^{-r \tau} N\left(d_{2}\right) & \begin{array}{l}
\text { long tine } \\
\text { calculati } \\
\text { Decemb }
\end{array} \\
\sigma_{E}=\frac{V N\left(d_{1}\right)}{E} \sigma_{V} & D D=\frac{V-D P}{V \sigma_{V}}
\end{array}\right. \\
d_{1}=\frac{\ln \frac{V}{D}+\left(r+\frac{1}{2} \sigma_{V}^{2}\right) \tau}{\sigma_{V} \sqrt{\tau}} \quad D D
\end{gathered}
$$

Calculation of stock volatility : This paper uses the historical volatility estimation method to obtain the volatility for the coming year from historical data. The stock price satisfies the log-normal spread. Assuming that $\mathrm{Si}$ is the closing price of week $i$, the log yield of the stock is

$$
\mathrm{Ui}=\ln \left(\frac{\mathrm{s}_{\mathrm{i}+1}}{\mathrm{~S}_{\mathrm{i}}}\right)
$$

The weekly volatility of stocks derived from the standard deviation estimate of stock returns Ui

$$
\sigma n=\sqrt{\frac{1}{n-1}} \sum_{i=1}^{n}\left(u_{i}-E(U)\right) \quad E(U)=\frac{1}{n} \sum_{i=1}^{n} U_{i}
$$

Annual volatility of the company's stock market value :

$$
d_{2}=d_{1}-\sigma_{V} \sqrt{ } \tau
$$

$\mathrm{E}$ is the market value of commercial bank equity, $\mathrm{V}$ is Bank asset market value, De is the total bank debt is the weighted sum of long-term debt and current debt, $r$ is market risk-free rate of return, $\tau$ is debt repayment period, generally considered to be 1 year, $D(d)$ is standard cumulative normal distribution function, $\sigma \mathrm{V}$ is the volatility of the asset value of an enterprise, $\sigma \mathrm{E}$ is the the volatility of corporate equity market value.We can use the formula to calculate the default distance DD of debt companies. DP is the default point value, which is somewhere between the company's current liabilities and total liabilities. The DD is the multiple of the standard deviation of the market value of the assets. From the MKV model defined by the default distance DD, the market value of the company's assets is lower than the probability of a default point, that is, the probability of default occurring in theory is $1-\mathrm{N}$ (DD).

Data Processing : This paper selects five large commercial banks of the Bank of China, Industrial and Commercial Bank of China, China Merchants Bank, China Construction Bank and Bank of Communications, which have been listed for a long time in Shanghai and Shenzhen, as the sample. The calculation period is January 1, 2014 to December 2014. 31st, December 31, 2014 as the base day

TABLE I CHINA'S FIVE COMMERCIAL BANKS' RATE OF RETURN FLUCTUATIONS

$\sigma e=\sigma n \times \sqrt{n} \quad$ Where $N$ is 53 weeks

Take Bank of China as an example, the calculation period is from January 1, 2014 to December 31, 2014, calculated using the formula above.

\begin{tabular}{|c|c|c|c|}
\hline Securities code & Securities abbreviation & $\begin{array}{l}\text { Weekly earnings } \\
\text { volatility } \sigma \mathrm{n}\end{array}$ & $\begin{array}{c}\text { Annual earnings } \\
\text { volatility } \sigma \mathrm{e}\end{array}$ \\
\hline 601988 & Bank of China & 0.039642 & 0.285863 \\
\hline 601398 & ICBC & 0.034117 & 0.245021 \\
\hline 601939 & Construction Bank & 0.040468 & 0.291819 \\
\hline 601328 & Bank of Communications & 0.049558 & 0.357368 \\
\hline 600036 & China Merchants Bank & 0.036619 & 0.264063 \\
\hline
\end{tabular}

$$
\begin{aligned}
& \mathrm{E}(\mathrm{U})=\frac{1}{n} \sum_{i=1}^{n} U_{i}=0.00929 \\
& \sigma \mathrm{n}=\sqrt{\frac{1}{n-1}} \sum_{i=1}^{n}\left(u_{i}-E(U)\right)=0.039642 \\
& \sigma \mathrm{e}=\sigma \mathrm{n} \times \sqrt{n}=0.285863
\end{aligned}
$$

The above calculation process is repeated and the daily volatility and annual volatility calculated from the data of the remaining four banks are calculated. 
Estimating asset value and asset value volatility :

$$
\begin{aligned}
& \left\{\begin{array}{l}
E=V N\left(d_{1}\right)-D e^{-r \tau} N\left(d_{2}\right) \\
\sigma_{E}=\frac{V N\left(d_{1}\right)}{E} \sigma_{V}
\end{array}\right. \\
& d_{1}=\frac{\ln \frac{V}{D}+\left(r+\frac{1}{2} \sigma_{V}^{2}\right) \tau}{\sigma_{V} \sqrt{\tau}}
\end{aligned}
$$

$$
d_{2}=d_{1}-\sigma_{V} \sqrt{\tau}
$$

This paper uses matlab software to solve the equations, and brings in the results obtained in the previous table.

TABLE II COMMERCIAL BANK ASSET VALUE AND Volatility

\begin{tabular}{|c|c|c|c|}
\hline Securities code & Securities abbreviation & $\begin{array}{c}\text { Asset value V (ten } \\
\text { thousand yuan) }\end{array}$ & $\begin{array}{c}\text { Asset value } \\
\text { volatility } \sigma \text { V }\end{array}$ \\
\hline 601988 & Bank of China & 1481600000 & 0.0231 \\
\hline 601398 & ICBC & 2018400000 & 0.0209 \\
\hline 601939 & Construction Bank & 1667900000 & 0.0294 \\
\hline 601328 & Bank of Communications & 611430000 & 0.0296 \\
\hline 600036 & China Merchants Bank & 469390000 & 0.0235 \\
\hline
\end{tabular}

Using the obtained $\mathrm{V}$ and $\sigma \mathrm{v}$ can further find the default distance DD and the default rate EDF of the five commercial banks, according to the following formula

$$
\begin{aligned}
& \mathrm{DD}=\frac{\mathrm{V}-\mathrm{DPT}}{\mathrm{V} * \sigma \mathrm{V}} \\
& \mathrm{EDF}=[1-\mathrm{N}(\mathrm{DD})] \times 100 \%
\end{aligned}
$$

TABLE III COMMERCIAL BANK DEFAULT RATE

\begin{tabular}{|c|c|c|c|}
\hline Securities code & Securities abbreviation & Default distance DD & EDF \\
\hline 601988 & & 2.1845 & 0.0145 \\
\hline 601398 & Bank of China & 2.6353 & 0.0042 \\
\hline 601939 & ICBC & 2.4175 & 0.0078 \\
\hline 601328 & Construction Bank & 1.768 & 0.0385 \\
\hline 600036 & China Merchants Bank & 2.5085 & 0.0061 \\
\hline
\end{tabular}

By comparing the bank's EDF value calculated by comparing the KMV model with the credit ratings given by Moody's rating agencies, it can be found that the KMV model can basically reflect the default rate of China's commercial banks, but its EDF value is lower than the EDF given by Moody's rating. The ratings of the five commercial banks mentioned above by Moody's were A1 in 2014, and the EDF values calculated by the KMV model were all above A1, but the default rates of the five banks ranked in line with expectations.

\section{$\beta$ Coefficient analysis}

The $\beta$ coefficient can be referred to as a risk assessment index that measures the price movement of a single stock or equity fund relative to the entire stock market. In William Sharp's single index model, the following formula can be obtained from the relationship between the yield of a single stock and the market rate of return [3]:

\section{$\mathrm{Rit}=\mathrm{Ai}+\beta \mathrm{i} \times \mathrm{Rmt}+\varepsilon \mathrm{it}$}

Among them, Rit denotes the yield of the i-th stock in the $\mathrm{t}$-th week; $\mathrm{Ai}$ is the intercept, which reflects the return rate of the stock $\mathrm{i}$ when the market yield is 0 ; Rmt refers to the market yield of the t-th week; cit denotes Random error.

\section{data processing}

This article selected the Shanghai Stock Exchange A Index as a substitute for the market portfolio, and calculated the Bank of China, Industrial and Commercial Bank of China, Construction Bank, and the factors of the weekly stock returns for the period from January 2008 to December 2014 that did not consider the cash dividend. The Bank of Communications and China Merchants Bank's 7-year beta values for seven years were used for analysis. Each bank selected approximately 358 data for regression analysis and about 50 data per year.

The $\beta$ value calculated by regression analysis using stata is shown in the following table 
TABLE IV COMMERCIAL BANK 2008-2014 B COEFFICIENT TABLE

\begin{tabular}{|c|l|l|l|l|l|l|}
\hline Bank & $\beta 08$ & $\beta 09$ & $\beta 10$ & $\beta 11$ & $\beta 12$ & $\beta 13$ \\
\hline $\begin{array}{c}\text { China Merchants } \\
\text { Bank }\end{array}$ & 1.183877 & 1.136787 & 1.0106333 & 0.982691 & 0.9853109 & 1.155966 \\
\hline Bank of China & 0.767878 & 0.4892621 & 0.6043801 & 0.540004 & 0.3659003 & 0.625967 \\
\hline Construction Bank & 0.911546 & 0.7980535 & 0.7907251 & 0.672345 & 0.4228385 & 0.851135 \\
\hline ICBC & 0.768524 & 0.6918342 & 0.8125205 & 0.532215 & 0.4155837 & 0.430131 \\
\hline $\begin{array}{c}\text { Bank of } \\
\text { Communications }\end{array}$ & 0.947022 & 1.138233 & 0.9603123 & 0.733322 & 0.6783308 & 1.207403 \\
\hline
\end{tabular}

Analysis of empirical results

\section{Credit risk analysis}

There are many factors that affect the credit risk, such as the bank's solvency, stability of assets, volatility of assets, and the size of banks' assets. This article can be used to measure the credit risk by EDF. It can be seen that the larger the assets of China's commercial banks, the stronger the solvency, the smaller the fluctuation of assets, the greater the default distance DD, the smaller the expected default rate, that is to say, the lower the credit risk. The opposite is also true.

It can be seen from the calculation results that the default distance DD and the expected default rate EDF calculated by the KMV model are in the opposite direction. After a simple linear regression, the two are basically changed linearly. Excluding the outliers can be said that the larger the DD, the EDF Smaller

Since the calculated KMV model can be compared with Moody's EDF and low EDF, the credit risk of China Commercial Bank has certain limitations. In the room for improvement of the model, the model can be slightly modified to make it to better simulate the credit risk of China's commercial banks.

By comparing the EDF values of 2012 and 2014 calculated by the KMV model, we can see that the expected default rates of all five commercial banks in China decreased in 2014, indicating that the credit risk control of commercial banks in China has improved in recent years. This is consistent with the current status of Moody's rating on the upward adjustment of China's commercial banks in recent years.

To sum up, using the KMV model to measure the credit risk of China's commercial banks has greater effectiveness and feasibility. The data acquisition is relatively simple, the calculation is simple, and the acquired data is processed into a well-written matlab software. You can get the EDF value. However, its existence error does not fully reflect the credit risk situation of China's commercial banks. It can use the results calculated by the KMV model to conduct initial guidance and policy formulation. There is still much room for improvement in this model.

\section{Systematic risk analysis}

According to the seven-year beta values of the five banks calculated in the above table, we find that 12 years ago, the beta mean value of the five major commercial banks in China was less than 1 , indicating that the systematic risk of China's commercial banks is less than that of China's financial institutions. Overall market risk [4].

We have seen that in the five years after the European debt crisis took place in 12 years, the beta values of China's five commercial banks showed a downward trend, indicating that the European debt crisis has played a warning role against China's commercial banks, and China has adopted appropriate countermeasures. Reduces the systematic risks of China's commercial banks and is very little affected by the European debt crisis.

From the above table, we can see that the $\beta$ value of China's commercial banks showed a significant upward trend in the 12 years to 14 years and 3 years, and the increase rate is relatively large. This shows that the systemic risk of systemic risks to commercial banks in China has decreased in the past three years. The risk has risen significantly, which is a bad signal for China's commercial banks.

It can be seen from the above table that the systemic risk of China's commercial banks is related to the size of commercial banks and the strength of banks. The systematic risks of China's banks and ICBC's two major commercial banks in China are higher than those of other banks. Lower beta, less systemic risk

There is a big gap between annual and annual beta values of China's commercial banks, and the repetitiveness is relatively strong. This shows that China's commercial banks have not yet had a very effective preventive measure against systemic risks.

\section{CONCLUSION}

China's commercial banks have higher credit risks and measures should be taken to reduce the credit risk of China's commercial banks. And the systematic risks of China's commercial banks have fluctuated in recent years and the systematic risks in the past three years have shown an upward trend. Measures should be taken to reduce systemic risks. We should adjust risk asset structure and increase asset liquidity, strengthen supervision of its own credit risk and establish its own rating mechanism and improve relevant financial laws and regulations and fundamentally reduce systemic risks.

\section{REFERENCES}

[1] Lu Xinxue, Zhao Kang. The Application of Foreign Credit Rating Model and Its Enlightenment to China. 2012

[2] Zhang Jingjing. Research on Commercial Bank Credit Risk Evaluation Based on BP-KMV Model. 2009

[3] Li Zhiying, Rao Haiqin. Thoughts on Systematic Risk Warning of Commercial Banks in China. 2014

[4] He Xiaobo. Commercial Bank Risk Early Warning System and Its Empirical Analysis.2001 